\title{
KELUARGA BEDA AGAMA DAN IMPLIKASI HUKUM TERHADAP ANAK
}

\author{
Muhammad Adi Suseno1, Lina Kushidayati ${ }^{2}$ \\ IAIN Kudus, IAIN Kudus \\ Email: adisuseno26@gmail.com ${ }^{1}$ \\ Email:linakushidayati@gmail.com²
}

\begin{abstract}
This article aims to find out the causes of different religions in the family at Dukuh Ngelo Karangrowo Undaan Kudus and the legal implications for children born into different religions in terms of Islamic law. This research is included in the category of field research using a qualitative approach method. Sources of data used in this study are primary data and secondary data. Primary data is obtained from interviews with various informants, while secondary data is in the form of laws and regulations, books, journal articles and others. The results and conclusions of this study indicate that the occurrence of different religions in the family at Dukuh Ngelo Karangrowo Invite Kudus is due to interfaith marriages that do not consider the legal aspects it causes, especially in terms of the inheritance of children born as a result of their marriage. The legal implication for biological children born to interfaith couples in the Islamic perspective is that children are prevented from obtaining inheritance from their parents so that grants are a solution for children to get justice for their parents' assets.
\end{abstract}

Keywords: Marriage with Different Religions, Marriage Law, Child Status

\begin{abstract}
Abstrak
Artikel ini bertujuan untuk mengetahui penyebab berbedanya agama dalam keluarga di Dukuh Ngelo Karangrowo Undaan Kudus dan implikasi hukum terhadap anak yang dilahirkan dalam keluarga beda agama ditinjau dari hukum Islam. Penelitian ini termasuk dalam kategori penelitian lapangan dengan menggunakan metode pendekatan kualitatif. Sumber data yang digunakan dalam penelitian adalah data primer dan data sekunder. Data primer didapatkan dari wawancara dengan berbagai informan, sedangkan data sekunder berupa peraturan perundang-undangan, buku, artikel jurnal dan lain-lain. Hasil dan sekaligus simpulan dari penelitian ini menunjukkan bahwa terjadinya beda agama dalam keluarga di Dukuh Ngelo Karangrowo Undangan Kudus disebabkan karena perkawinan beda agama yang tidak memandang dari aspek hukum yang ditimbulkannya terutama dalam hal kewarisan terhadap anak yang dilahirkan hasil perkawinannya. Implikasi hukum bagi anak kandung yang dilahirkan dari pasangan beda agama dalam perspektif Islam adalah anak terhalang untuk mendapatkan warisan dari orang tuanya sehingga hibah menjadi solusi bagi anak untuk mendapatkan keadilan atas harta orang tuanya.
\end{abstract}

Kata Kunci: Perkawinan Beda Agama, Hukum Perkawinan, Status Anak 


\section{PENDAHULUAN}

Perkawinan adalah perjanjian antara laki-laki dan perempuan untuk kehidupan rumah tangga sejak mengadakan perjanjian melalui akad. Yang dimaksud perjanjian disini tidak secara lahir tetapi juga secara batin disertai keyakinan kepada Tuhan Yang Maha Esa. Hal ini tertuang dalam Undang-Undang Republik Indonesia Nomor 1 Tahun 1974 tentang Perkawinan, menyatakan bahwa: "Perkawinan ialah ikatan lahir dan batin antara pria dengan dengan wanita sebagai suami isteri dengan tujuan membentuk keluarga (rumah tangga) yang bahagia dan kekal berdasarkan Ketuhanan Yang Maha Esa.

Walaupun memiliki hukum perkawinan nasional yang berfungsi untuk mengatur masalah perkawinan, namun tidak bisa dipungkiri bahwa pada kenyataannya masih banyak masyarakat yang masih menggunakan aturan adat istiadat dari masing-masing agama maupun sukunya masing-masing. Sehingga dalam melangsungkan perkawinan ada banyak yang melanggar aturan hukum yang sudah diatur. Salah satu diantaranya ialah perkawinan berbeda agama dan konversi agama (Makelaw, 2013: 132).

Kenyataan dalam kehidupan masyarakat bahwa keluarga beda agama itu terjadi sebagai realitas yang tidak dipungkiri. Pada prakteknya banyak pasangan yang ingin hidup bersama namun tidak ada perkawinan karena didasari dengan agama atau kepercayaan yang berbeda. Dalam konteks ini mereka hanya berpegang dalam komitmen yang sudah dibuat oleh kedua belah pihak. Namun persoalannya adalah ketika komitmen tidak dapat berjalan dengan baik, maka hubungan tersebut akan menjadi rumit, dan timbul akitbat hukum yang berakibat pada terganggunya kerukunan hidup berumah tangga karena tidak ada peran agama dalam tujuan ikatan perkawinan.

Agama membentuk sistem nilai dalam diri. Segala bentuk simbol keagamaan dan upacara ritual sangat berperan dalam pembentukan sistem nilai dalam diri, setelah terbentuk, seseorang akan mampu menggunakan sistem nilai ini dalam memahami, mengevaluasi, serta menafsirkan situasi dan pegalaman (Saptiani dan Setiawan, 2008: 327).

Kenyatannya dalam masyarakat, sering kali dijumpai fenomena konversi agama, entah karena ketidakpuasan pada agama asal, trauma yang berpengaruh pada keyakinan seseorang, takjub dengan fundamental agama yang akan dianut, ataupun karena mempunyai pasangan yang berbeda agama. Dalam hal ini akibat dari konversi agama sama riskannya dengan perkawinan beda agama terhadap pondasi rumah tangga selanjutnya, perbedaaan pendapat dan ketidakserasian merupakan suatu hal yang lumrah dalam sebuah keluarga beda agama, karena pondasi keyakinan mereka berbeda. 
Penelitian ini mengkaji tentang penyebab bedanya agama dalam keluarga dan implikasi hukum terhadap anak ditinjau dari hukum Islam. sehingga fokus dalam kajian ini diantaranya bagaimana latar belakang perbedaan agama keluarga, bagaimana pemahaman masyarakat dan tokoh agama mengenai keluarga beda agama dan dampaknya terhadap anak, bagaimana status hukum keluarga beda agama, dan bagaimana dampak hukum keluarga beda agama terhadap anak. Hasil penelitian ini diharapkan dapat menjadi rujukan dalam pengembangan hukum perkawinan di Indonesia dan dapat dijadikan pertimbangan bagi masyarakat terutama dalam melangsungkan perkawinan terutama bagi mereka yang berbeda keyakinan meskipun perkawinan beda agama dalam konteks Indonesia diperbolehkan sepanjang dalam pelaksanaan perkawinan dilakukan berdasarkan

\section{METODE PENELITIAN}

Artikel berdasarkan atas penelitian lapangan (field reserch) dengan pendekatan kualitatif. Lokasi yang penulis pilih adalah di Undaan, Kudus. Data dalam penelitian ini diperoleh melalui wawancara dengan informan dan data sekunder diperoleh dari peraturan perundangundangan dan sumber referensilain. Data yang diperoleh kemudian dianalisis dengan menggunakan analisis deskriptif kualitatif.

\section{PEMBAHASAN}

\section{Latar Belakang Perbedaan Agama dalam Keluarga}

Menurut data survei fenomena keluarga beda agama di Desa Karangrowo di alami oleh keluarga bapak Hendra (nama samaran) yang menganut agama Kristen dengan ibu Susan (nama samaran) yang beragama Islam. Sebelum menikah dari kecil bapak Hendra bertempat tinggal di daerah Gunung Kidul Yogyakarta yang merupakan tempat kelahirannya, bapak Hendra merupakan anak sulung dari 4 bersaudara keluarga tersebut, dan karena itulah bapak Hendra mendapatkan dukungan penuh dari saudara dan orang tuanya agar mengeyam pendidikan setinggi tingginya demi mengangkat harkat martabat keluarga.

Menurut pernyataan bapak Hendra, karena dulu belum terdapat TK (Taman Kanak-kanak) seperti sekarang, jenjang pendidikannya pun langsung dimulai dari SD, SMP, kemudian SMA yang kesemuanya itu beliau tempuh di Gunung Kidul Yogyakarta. Setelah lulus SMA dengan hasil nilai yang bagus, beliau bertekad untuk melanjutkan jenjang pendidikan agar mempermudah dalam mencari pekerjaan di masa datang. Dengan bermodal tekad dan dukungan dari keluarga, beliau mengadu nasib di ibu kota Jawa Tengah yakni Semarang untuk melanjutkan pendidikannya, dan pada akhirnya beliau memasuki suatu 
perguruan tinggi di Semarang yaitu UT Semarang dan mengambil jurusan PGSD (Pendidikan Guru SD). Disinilah awal mula cerita cinta antara bapak Hendra dengan Ibu Susan dimulai (Wawancara dengan Hendra, 25 Februari 2020).

Ibu Susan berdomisili di Kudus yang juga merupakan tempat kelahiran beliau. Dalam riwayat pendidikannya, beliau sama seperti bapak Hendra yakni langsung dimulai dari SD karena pada waktu itu belum ada TK, dari SD sampai SMA beliau tempuh di Kudus sendiri, baru kemudian setelah lulus SMA beliau melanjutkan pendidikannya di UT Semarang dengan mengambil jurusan PGSD.

Singkat cerita, Bapak Hendra dan ibu Susan menikah pada tahun 1990 yang dilangsungkan di Catatan Sipil Gunung Kidul Yogyakarta, sampai sekarang mereka di karuniai 2 anak yang kesemuanya laki-laki. Anak pertama bernama Saipul (nama samaran) beragama Islam, jenjang pendidikan terakhirnya S1 (Strata 1) di Universitas Dian Nusantoro Semarang mengambil jurusan Teknik, saat ini ia sudah membangun bahtera rumah tangga sendiri dan bertempat tinggal di Lumajang di rumah istrinya yang merupakan anak sulung, karena dalam adat Jawa anak sulung tidak boleh meninggalkan orang tuanya dalam artian tetap satu atap meskipun sudah menikah sekalipun, dengan harapan si anak dapat merawat orang tua mereka. Anak kedua bernama Cahyo (nama samaran) beragama Islam, Ia sekarang masih menempuh pendidikan di SMK 3 Kudus. Cahyo inilah yang saat ini tinggal bersama orang tuanya di Desa karangrowo Undaan Kudus.

Bapak Hendra dan ibu Susan sebelum menikah beragama Kristen, kemudian mereka menikah pada tahun 1990 yang langsungkan di Catatan Sipil Gunung Kidul Yogyakarta. Setelah menikah mereka memutuskan bertempat tinggal di Desa Karangrowo Kecamatan Undaan Kabupaten Kudus, meskipun bapak Hendra yang notabene sebagai anak sulung yang seharusnya tinggal bersama orang tuanya. Namun, dengan keteguhan prinsip dan alasan keluarga beliau memutuskan untuk tinggal di Kudus yang merupakan tempat kelahiran istrinya.

Bapak Hendra berprofesi sebagai guru SD 1 Karangrowo dengan usaha sampingan membuka bengkel kecil-kecilan, begitu pula dengan istrinya berprofesi sebagai guru SD juga memiliki usaha sampingan dengan membuka toko kelontong di depan rumah mereka(Hendra, wawancara: 2020). Gambaran letak rumah bapak Hendra yakni dekat dengan SD 1 Karangrowo untuk memudahkan beliau menjalankan profesinya dan dekat dengan Masjid Al Hidayah Dukuh Ngelo Desa Karangrowo, dan mungkin inlah salah satu faktor ibu Susan memilih menjadi mualaf.

Menurut pernyataan Ibu Susan, beliau menjadi mualaf karena dorongan dari hati sendiri bukan karena ajakan dari luar, setelah 
Keluarga Beda Agama dan Implikasi Hukum....

bermusyawarah dengan suaminya yakni bapak Hendra, beliau mencurahkan segala sebab ingin menjadi mualaf dan bapak Hendra pun sebagai kepala keluarga sekaligus penganut agama Kristen yang taat tidak menghalangi ibu Susan yang ingin menjadi mualaf (Susan, Wawancara: 2020). Karena bapak Hendra memiliki Prinsip bahwasannya menikah ialah komitmen sehidup semati tidak perduli dengan keadaan yang terjadi meskipun berbeda keyakinan sekaligus, yang terpenting dalam kehidupan keluarga yakni saling menyayangi, toleransi dan selalu ingat alasan mengapa dulu memutuskan menikah.

Bapak Hendra dan Ibu Susan dikaruniai 2 anak yang keduanya memeluk agama Islam. Dalam memilih keyakinannya bapak Hendra sebagai pemeluk agama Kristen dan ibu Susan yang memeluk agama Islam tidak mempengarui sang anak untuk mengikuti agama yang mereka yakini, akan tetapi mereka membiarkan sang anak mencari jati dirinya dan memilih keyakinnya karena itu sebagian proses dari pendewasaan diri. Alhasil kedua anak tersebut memilih memeluk agama Islam dan sekarang mereka menjadi muslim yang taat akan agamanya.

Menurut Bapak Subhan yakni tiap tiap bayi yang keluar dari rahim ibunya itu dalam keadaan fitrah (Islam), kedua orang tuanya lah yang membuat dia majusi, nasrani atau yahudi. Jadi peran orang tua sangatlah penting bagi seorang anak dalam memilih keyakinannya, ukuran seorang anak dalam menentukan kayakinannya yakni sampai dia baligh, biar dia menetukan pilihannya tanpa adanya pengaruh dan paksaan dari siapapun termasuk orangtua. Kalaupun sudah menentukan pilihannya sebagai orang tua wajib mengingatkan seorang anak agar patuh terhadap agama yang dipilihnya (Wawancara dengan Subhan, 28 Februari 2020).

\section{Pemahaman Pelaku dan Tokoh Agama Mengenai Hukum Keluarga Beda Agama}

Hukum ialah suatu aturan-aturan yang dibentuk untuk di taati dan sebagai landasan seseorang menjalankan hidup, pelanggarnya akan dikenai sanksi. Untuk itulah persoalan hukum di Indonesia sangatlah kompleks karena simbolis penegak hukumnya kurang cakap dan lalai dalam melihat fenomena fenomena yang ada.

Keluarga beda agama merupakan salah satu fenomena hukum yang tersorot di Indonesia, karena dalam keluarga beda agama terdapat banyak faktor yang mempengaruhi kehidupan kedepannya, dan banyak keluarga beda agama yang kandas di tengan jalan entah karena perselisihan pendapat yang disebabkan berbedanya keyakinan dalam keluarga, atau entah demi hukum kandasnya keluarga beda agama, namun hal itu tidak berlaku bagi keluarga beda agama bapak hendra dan ibu Susan (Wawancara dengan Hendra, 25 Februari 2020). 
Menurut Bapak Hendra dan ibu Susan dalam persoalan hukum keluarga beda agama, beliau kurang menyadari baik dari hukum positif maupun hukum agama (Wawancara dengan Susan,25 Februari2020). Namun apapun itu beliau tidak peduli karena kembali lagi dalam prisipnya menikah ialah komitmen sehidup semati tidak perduli dengan keadaan yang terjadi meskipun berbeda keyakinan sekaligus, yang terpenting dalam kehidupan keluarga yakni saling menyayangi, toleransi dan selalu ingat alasan mengapa dulu memutuskan menikah. Karena ukuran sukses dalam menikah itu bukan tentang seberapa cepat mereka kaya, bukan tentang seberapa cepat mempunyai keturunan tapi tentang bagaimana mereka melewati rintangan, mempertahankan, bahkan memadu sayang sampai namanya terukir dalam pemakaman.

Menurut Bapak Subhan selaku tokoh agama masyarakat Desa Karangrowo keluarga beda agama merupakan suatu hal yang dalam Islam tidak memperbolehkannya. Karena salah satu syarat calon mempelai dalam syariat yakni beragama Islam, sedangkan jika perbedaan agama muncul setelah perkawinan atau mualaf hukumnya yakni putus pernikahan tersebut menurut syariat Islam, kecuali suami istri tersebut mualaf secara bersamaan (Wawancara dengan Subhan, 28 Februari 2020).

\section{Pemahaman Pelaku dan Tokoh Agama Mengenai Dampak Hukum Keluarga Beda Agama Terhadap Anak}

Anak merupakan harapan sekaligus salah satu tujuan seseorang melangsungkan pernikahan, dikatakan anak yang sah yakni anak yang dilahirkan dari pernikahan yang sah, dan pernikahan yang sah yakni pernikahan yang dilakukan sesuai kepercayaan dan agama masingmasing. Jadi jika perkawinannya tidak sah maka anak yang dilahirkanpun juga tidak sah menurut hukum positif dan hukum Islam

Dalam menyikapi keluarga beda agama ini sangatlah berkaitan erat pada ranah hukum baik itu mengenai keabsahan perkawinan dan dampak hukum terhadap anak. Masalah soal agama yang di anut anak, nashab sekaligus waris menjadi perhatian penting bagi keluarga beda agama. Menurut Bapak Hendra problem soal dampak hukum terhadap anak dalam keluarga beda agama merupakan hal pasti dan beliau sendiri sudah menyadari, menyikapi problem tersebut diperlukan keleluasan, tidak memaksakan kehendak kepada anak dalam memilih keyakinan, namun tetap memberikan pengetahuan kepada anak agar dalam memilih keyakinan terdapat pertimbangan yang jelas (Wawancara dengan Hendra, 25 Februari 2020). Meskipun pada akhirnya memilih agama Islam namun bapak Hendra tetap mengapresiasi apa yang menjadi pilihan anaknya, dengan cara saling mengingatkan dalam hal apapun yang di anjurkan dari agama masing-masing termasuk dalam hal ibadah, karena menurutnya yang terpenting ialah keutuhan rumah tangga. 
Keluarga Beda Agama dan Implikasi Hukum....

Perhatian khusus dalam keluarga beda agama setelah anak memutuskan memeluk agama yang dianutnya yakni masalah waris. Waris merupakan pembagian harta peninggalan orang tua kepada ahli warisnya, meskipun dalam prakteknya terdapat macam pembagian waris yakni waris perdata, waris adat dan waris islam. Bapak Hendra selaku kepala keluarga beda agama yang menganut agama Kristen tidak terlalu perduli soal harta waris, biarlah anak yang memutuskan, karena bekal yang kekal dan bermanfaat bagi anak di masa depan melebihi waris yakni ilmu, harta waris bisa saja habis tapi ilmu tidak dapat habis bahkan bisa mendatangkan harta melebihi waris. Maka dari itu beliau mengatakan biarlah hartaku habis yang terpenting anak bisa mengenyam pendidikan yang tinggi (Wawancara dengan Hendra, 25 Februari 2020).

Menurut pak Subhan problem keluarga beda agama memang sangat berdampak terhadap keturunan. Bilamana dalam keluarga tersebut istri beragama Islam dan suami non Islam maka nashab anak kepada bapaknya terputus dan dialihkan ke nashab ibunya, karenanya hukum waris islam tidak bisa diterapkan pada keluarga beda agama dan solusi agar anak mendapatkan harta dari jerih payah orang tuanya yakni hibah, dengan syarat saat menghibahkan harta tersebut orang yang menghibahkan dalam keadaan masih hidup (Wawancara dengan Subhan, 28 Februari 2020).

\section{Status Hukum Keluarga Beda Agama}

Pernikahan adalah suatu perbuatan yang sangat dianjurkan oleh Rasulallah SAW, akadnya merupakan suatu perjanjian dan ikatan yang tidak boleh dianggap main-main. Karenanya pernikahan dalam Islam itu bukanlah tentang hubungan semata atau kontrak keperdataan biasa, tetapi juga mengandung nilai ibadah sebagaimana tertuang dalam Pasal 2 Kompilasi Hukum Islam bahwasannya "Pernikahan merupakan Akad yang sangat kuat untuk mentaati perintah Allah dan pelaksanaannya merupakan ibadah".

Hukum perkawinan merupakan landasan dasar untuk melakukan perkawinan, dalam Islam segala hukum termasuk hukum perkawinan bersumber dari Al-Qur'an dan Hadis yang kemudian perinciannya di jelaskan dalam kitab-kitab fiqih yang sekarang ini. Pada dasarnya setiap hukum agama telah menetapkan kedudukan seseorang dengan keimanan dan ketakwaan, dengan kata lain apa yang seharusnya dilakukan dan apa yang tidak seharusnya dilakukan. Dalam kaitannya perkawinan, setiap agama sesungguhnya tidak membenarkan perkawinan yang berlangsung tidak seagama (Aristoni \& Abdullah, 2016,: 81). Hukum Islam itu bersifat dinamis karena dalam penerapannya melihat konteks yang ada dan mementingkan manfaat serta menjauhi mudharat. 
Sementara itu, perkawinan dalam perspektif hukum Kristen Katolik merupakan persekutuan hidup antara pria dan wanita yang didasarkan atas ikatan cinta kasih yang total dengan persetujuan bebas dari keduanya dan tidak dapat ditarik kembali. Dengan kata lain, bahwa perkawinan dalam pandangan agama Kristen Katolik hakikatnya adalah bukan hanya merupakan perbuatan yang bertalian dengan cinta antara suami istri, akan tetapi juga harus mencerminkan kesetiaan dan sifat Allah yang penuh cinta kasih yang tidak dapat dipisahkan. Kemudian menurut hukum ini perkawinan dapat dikatakan sah apabila kedua calon mempelai telah dilakukan baptis (Aristoni \& Abdullah, 2016: 82).

Melihat fenomena dan pluralitas pernikahan yang sekarang ini, maka hukum pernikahanpun bisa jadi wajib, haram, sunnah, makruh dan mubah tergantung kondisi kedua calon mempelai., Dalam penelitian ini, keluarga beda agama merupakan salah satu fenomena dalam pernikahan yang terjadi saat ini dan mendapakat perhatian khusus dikarenakan berkaitan erat dengan hukum pernikahan itu sendiri. Keluarga beda agama terjadi sebab 2 hal yakni pernikahan beda agama dan konversi agama.

Penikahan beda agama hakikatnya merupakan pernikahan yang di langsungkan oleh calon mempelai yang berbeda agama, dalam Pasal 2 ayat 1 Undang-Undang Republik Indonesia Nomor 1 Tahun 1974 tentang Perkawinan menegaskan bahwa "Perkawinan yang sah adalah perkawinan yang dilaksanakan menurut agama dan kepercayaannya masing-masing" (Amalia, 2016: 29). Jadi jika dalam agama memperbolehkan pernikahan tersebut maka hukum positif juga memperbolehkan.

Menurut jumhur ulama, pernikahan beda agama dalam Islam jelas di larang sebab dalam hukum pernikahan Islam syarat kedua mempelai baik laki-laki maupun perempuan yang akan melaksanakan pernikahan haruslah beragama Islam. Berbeda dengan perkawinan beda agama yang jelas di larang dalam hukum pernikahan, konversi agama menurut Max Heirich yakni suatu tindakan dimana seseorang atau kelompok orang masuk atau berpindah kesuatu sistem kepercayaan atau perilaku yang berlawanan dengan kepercayaan sebelumnya (Sukiman, 2005: 69). Konversi agama yang dilakukan setelah pernikahan jelaslah mengubah hukum pernikahan tersebut, banyak ulama berpendapat bahwa konversi agama yang dilakukan setelah pernikahan hukumnya fasakh (putus).

Fasakh merupakan suatu bentuk pemutusan hubungan pernikahan yang dapat digunakan oleh suami atau istri untuk melakukan perceraian, dalam berbagai literatur disebutkan bahwa fasakh dalam arti bahasa adalah batal atau rusaknya suatu pernikahan. Perceraian dengan fasakh ini berkonsekuensi dalam hubungan pernikahan karena ketika sudah di hukum fasakh suami istri tidak dapat rujuk kembali, namun untuk dapat 
Keluarga Beda Agama dan Implikasi Hukum....

melanjutkan hubungan pernikahan tersebut harus dilaksanakan akad nikah yang baru.

Sayyid Sabiq berpendapat bahwa fasakh bisa terjadi karena syaratsyarat yang tidak terpenuhi pada akad nikah atau karena hal-hal lain yang datang kemudian membatalkan kelangsungan pernikahan. Berdasarkan pandangan ini dapat diketahui bahwa fasakh sebagai salah satu bentuk perceraian bertujuan mengubah atau membatalkan hubungan suami istri melalui putusan hakim, karena setelah berlangsungnya pernikahan diketahui dan diketemukan adanya syarat-syarat yang tidak terpenuhi dalam perkawinan tersebut (Amalia, 2016: 93).

Meskipun dalam keluarga beda agama bapak Hendra dan ibu Susan, ibu Susan sebagai mualaf memiliki hak untuk mengajukan fasakh ke pengadilan. Akan tetapi beliau tidak mengajukannya, karena yang terpenting bagi beliau yakni keutuhan rumah tangga dan menjaga komitmen dengan bapak Hendra untuk sehidup semati apapun dan bagaimanapun kondisinya serta menjaga masa depan anaknya.

\section{Dampak Hukum Keluarga Beda Agama Terhadap Anak}

Pernikahan merupakan bentuk kedewasaan sepasang kekasih dalam kehidupan untuk membangun sebuah bahtera rumah tangga yang baru. Tentunya calon pengantin sudah meneguhkan tekad meraka dan mampu bertanggung jawab dalam kehidupan pernikahan mereka termasuk jika mereka di karuniai keturunan.

Anak merupakan salah satu hal yang sangat didambakan bagi seseorang yang sudah menikah, banyak orang orang yang di karuniai keturunan tpi mereka tak mampu bertanggung jawab dengan baik terhadap tumbuh kembang sang anak, namun disisi lain banyak juga sepasang suami istri yang mengharapkan mempunyai keturunan. Jadi anak merupakan tanggung jawab penuh orang tua dalam hal pendidikan, tumbuh kembang dan sebagianya sampai sang anak mampu membangun keluarga kecilnya sendiri, hal ini sesuai dengan salah satu tujuan syariat Islam (Maqasid al-Syariah) yakni Hifzdu Nasl (memelihara keturunan).

Hukum Islam menegaskan bahwa pada dasarnya seorang anak adalah sah, apabila pada permulaan kehamilan ibu anak dan laki-laki yang menyebabkan kehamilan dalam hubungan perkawinan yang sah. Maka dalam keluarga beda agama tentunya anak yang dilahirkanpun tidak sah. Kemudian dalam keluarga beda agama, anak menjadi suatu hal yang sangat diperhatikan karena hak mereka terbatasi atas perbedaan keyakinan kedua orang tuanya dan juga secara tidak langsung berpengaruh pada rohani sang anak tentang agama apa yang akan di anutnya nanti.

Setiap bayi yang keluar dari rahim ibunya itu dalam keadaan fitroh (islam), kedua orang tuanyalah yang membuat ia menjadi majusi, nasrani 
dan yahudi. untuk itu orang tua sangatlah berpengaruh terhadap agama apa yang akan di anut anaknya nanti. Tetapi berbeda dalam keluarga beda agama karna agama yang di anut orang tuanya berbeda, hal ini menyebabkan sang anak merasa bimbang dalam memilih keyakinan. Namun yang terpenting adalah memberi pengetahuan keagamaan kepada anaknya sedari dini biar sang anak mampu menentukan pilihannya nanti, ketika sudah baligh biarkan sang anak memilih keyakinannya sendiri tanpa adanya pengaruh dan paksaan dari siapapun termasuk orang tuanya.

Dampak dari keluarga beda agama terhadap anak yakni terputusnya nashab orang tuanya jika bapaknya yang non muslim dan nashabnya di alihkan kepada ibunya. Dengan perumpamaan seperti dalam kisah nabi Isa As yang dinashabkan kepada ibunya (Sarong, 2010: 171). Dalam QS. Maryam ayat 17-20.

Artinya: Maka ia Mengadakan tabir (yang melindunginya) dari mereka; lalu Kami mengutus roh Kami kepadanya, Maka ia menjelma di hadapannya (dalam bentuk) manusia yang sempurna. Maryam berkata: "Sesungguhnya aku berlindung dari padamu kepada Tuhan yang Maha pemurah, jika kamu seorang yang bertakwa". ia (Jibril) berkata: "Sesungguhnya aku ini hanyalah seorang utusan Tuhanmu, untuk memberimu seorang anak laki-laki yang suci". Maryam berkata: "Bagaimana akan ada bagiku seorang anak laki-laki, sedang tidak pernah seorang manusiapun menyentuhku dan aku bukan (pula) seorang pezina!"

Surat di atas menjelaskan lahirnya nabi Isa As yang tanpa seorang bapak, yang kemudian bernashab kepada ibunya yakni Isa bin maryam. Hal ini menjadi salah satu dasar dalam keluarga beda agama mengalihkan nashab kepada ibunya, karena jika bapaknya nonmuslim maka keberadaan seorang bapak tidak diperhitungkan (Sarong, 2010: 171). Nasab merupakan hal yang berkaitan erat dengan hak waris. Karna waris merupakan pembagian peninggalan harta kekayaan orang tua kepada ahli waris yang dalam hal ini terkait dengan nashab si pewaris.

Anak dalam keluarga beda agama tidak akan mendapat hak waris dikarenakan nashab yang terputus kepada bapaknya. Namun sebagai orang tua tentunya dengan beribu kasih sayang ingin membuat anaknya bahagia dalam hal apapun dan bagaimanapun jalannya termasuk ingin sang anak agar bisa merasakan harta peninggalannya yang merupakan jerih payahnya dulu yakni dengan jalan wasiat atau hibah yang dapat dilaksanakan dalam batas sepertiga harta peninggalan. Hal ini telah diformalkan dalam kompilasi hukum Islam Pasal 209 KHI yang menetapkan bagian maksimum sepertiga bagian tidak dari bagian warisan, tetapi berupa bagian wasiat (Sarong, 2010: 177). 
Keluarga beda agama yang di alami oleh bapak Hendra dan ibu Susan memiliki banyak problem hukum yang juga berdampak kepada anaknya. Anak dari keluarga beda agama bapak Hendra dan ibu Susan menurut hukum Islam tidak sah, karena perbedaan agama dalam keluarga bapak Hendra dan ibu Susan terjadi setelah penikahan berlangsung namun sebelum mempunyai anak atau sebelum kehamilan, karena pada dasarnya anak adalah sah, apabila pada permulaan kehamilan ibu anak dan laki-laki yang menyebabkan kehamilan dalam hubungan perkawinan yang sah, maka nasab anak tersebut terputus dari bapaknya dan di alihkan ke ibunya.

\section{SIMPULAN}

Berdasarkan paparan dalam pembahasan di atas, maka dapat disimpulkan bahwa penyebab bedanya agama dalam keluarga dikarenakan adanya pertalian hubungan perkawinan beda agama yang mana pasangan perkawinan beda agama tersebut sebelumnya tidak mempertimbangkan aspek hukum yang ditimbulkannya. Baginya melangsung perkawinan adalah komitmen sehidup semati tidak peduli dengan keadaan yang terjadi meskipun berbeda keyakinan sekaligus, yang terpenting dalam kehidupan keluarga yakni saling menyayangi dan asling menghargai (toleransi). Dalam hukum Islam perkawinan beda agama memiliki implikasi hukum yaitu terputusnya nasab anak kepada bapaknya dan dialihkan ke nasab ibunya, sehingga berkonsekuensi anak tidak dapat mewarisi harta benda orangnya sebab hukum Islam tidak dapat diterapkan dalam perkawinan beda agama, maka solusi yang dapat dilakukan adalah dengan cara hibah dengan syarat orang tua yang menghibahkan dalam keadaan masih hidup.

\section{DAFTAR PUSTAKA}

\section{Buku-buku}

Jamaludin dan Nanda Amalia, Buku Ajar Hukum Perkawinan, Lhokseumawe: Unimal Press, 2016.

Mulyana, Deddy. Metodologi Penelitian Kualitatif Paradigma Baru Ilmu Komunikasi dan Sosial Lainnya. Bandung: Remaja Rosdakarya. 2001.

Mathlub, Abdul Majid Mahmud, Panduan Hukum Keluarga Sakinah. Surakarta: Era Intermedia. 2005.

Sarong, Hamid. Hukum Perkawinan Islam di Indonesia. Banda Aceh: PeNA 2010.

Shidiq, Sapiudin. Fikih Kontemporer. Jakarta: Prenada Media Group, 2016. 
Syarifuddin, Amir. Hukum Perkawinan Islam di Indonesia: Antara Figh Munakahat dan Undang-Undang Perkawinan. Jakarta: Kencana, 2006.

Suhadi, Kawin Lintas Agama Perspektif Kritik Nalar Islam. Yogyakarta: LKiS, 2006.

\section{Jurnal-jurnal}

Agustin, Fitria. (2018). Kedudukan Anak Dari Perkawinan Beda Agama Menurut Hukum Perkawinan Indonesia. Ajudikasi: Jurnal Ilmu Hukum, 2(1)

Aristoni, \& Abdullah, J. (2016). 4 Dekade Hukum Perkawinan di Indonesia: Menelisik Problematika Hukum Dalam Perkawinan di Era Modernisasi. Yudisia, 7(1).

Foresty, Cindy Silvy., M Khoirul Hadi al-Asy Ari, dan Entin Hidayah. Problem Perlindungan Hukum Terhadap Perkawinan Beda Agama di Indonesia: Studi Undang-Undang Nomor 1 Tahun 1974 serta UndangUndang Nomor 39 Tahun 1999 dan Hukum Islam. Yudisia: Jurnal Pemikiran Hukum dan Hukum Islam. Vol. 7, no. 1, (2016).

Jane Marlen Makelaw, Akibat Hukum Dari Perkawinan Beda Agama Di Indonesia, Jurnal Lex privatum, Vol. 1, No. 2 (2013)

Makelaw, Jane Marlen. Akibat Hukum Dari Perkawinan Beda Agama Di Indonesia. Jurnal Lex Privatum, Vol. 1. No. 2 (2013).

Rani Dwi Saptiani dan Jeni lukito Setiawan, Konversi Agama Dalam Kehidupan Pernikahan, Jurnal Humaniora, Vol. 20, No. 3, (2008)

Sukiman, Konversi Agama (Studi Kasus Pada Dua Keluarga di Dusun Pasekan Mugowaharjo, Depok, Sleman), Jurnal AplikasiI lmu-ilmu Agama, Vol. VI, No. 1 (2005)

Saptiani, Rani Dwi dan Jeni lukito Setiawan, Konversi Agama Dalam Kehidupan Pernikahan, Jurnal Humaniora. Vol. 20. No. 3. (2008). 